(C) 1983 ISIJ 樋型炬でのソーダ灰による溶銑連続精錬と溶銑，論 文 スラグの混合特性

\author{
山本 里見* ·石川 英毅* ·藤掛 陽蔵* \\ 吉井 正孝*2 ・坂口 生一*3 ・梶岡 博幸*4
}

\title{
Refining of Hot Metal with Soda Ash in Trough-type Continuous Refining Furnace and Fluid Flow Characteristics of Hot Metal and Slag in the Furnace
}

\author{
Satomi Yamamoto, Hidetake Ishikawa, Yozo FujIKake, \\ Masataka YoshII, Shoichi SAKAguaHI, and Hiroyuki KAJIOKA
}

\begin{abstract}
Synopsis:
The multi-stage steelmaking process with soda ash $\left(\mathrm{Na}_{2} \mathrm{CO}_{3}\right)$ was proposed. Dephosphorization and desulphurization of hot metal, the most important unit processes in the process, were studied. Experiments on the continuous refining of hot metal with $\mathrm{Na}_{2} \mathrm{CO}_{3}$ were carried out using the trough-type continuous refining furnace. The furnace was divided in two chambers and the first (upper stream) chamber was provided for desiliconization with oxygen and iron ore and the second one was for dephosphorization and desulphurization with $\mathrm{Na}_{2} \mathrm{CO}_{3}$. In the second chamber the hot metal and slag flowed in counter currents.

The furnace was able to process the hot metal at a rate of $45 \mathrm{t} / \mathrm{h}$ and the refined hot metal was transported to the steelmaking shop. The operation for 120 hours in campaigns proved the stability in reaction temperature and low wear rate of the refractory in the refining section. By analysing the tracer concentration in the exit stream with the mixed model, Peclet numbers for the hot metal and the slag flows were estimated as 6.7 and 2.0 respectively.
\end{abstract}

\section{1. 緒言}

日本に和ける新製鋼法開発の流れのひとつとして, 多 段製鋼法をあげることがでさる．この多段製鋼法は精鍊 工程を脱けい, 脱りん, 脱硫拉よび脱炭の素反応工程に 分け，おの拈のが最適条件下で行われるように系全体を 組み立て, 溶製コストの低減, 省エネルギーをはからら とする製鋼プロセスである.

この多段製鋼法は, 原料事情の悪化, 鋼材規格の高級 化などに対処できるだけでなく，ごく少量のスラグ下で 行う脱炭精鍊の利点, 寸なわち鉄歩留りの向上, 副材料 の節減などを容易に手にすることができると考学られ る.

多段製鋼法の基本に溶銑の脱りん，脱硫精錬がある. 精錬用副材料として, $\mathrm{Na}_{2} \mathrm{CO}_{3}$ 系(1) 4), $\mathrm{CaO}$ 系5) 副材 料を用いた研究が報告されているが，筆者らはッーダ死
$\left(\mathrm{Na}_{2} \mathrm{CO}_{3}\right)$ を用いた溶銑の連続精鍊について研究して おり ${ }^{6)}$ ，本報はその一部を報告するものである.

$\mathrm{Na}_{2} \mathrm{CO}_{3}$ を用いた溶銑の精鍊の特色として，同 時 脱 りん脱硫が可能でありしかもその分配比が大きいことの ほかに，スラグが流動性に富むので溶銑との分離が容易 となり,さらにとのスラグから $\mathrm{Na}_{2} \mathrm{CO}_{3}$ を回収できる ことなどをあげることができる. $\mathrm{Na}_{2} \mathrm{CO}_{3}$ を用いた精鍊 の特色を組み合わせると, 新しい製鋼システム2)3)(Fig. 1)が考方られる．溶鉄 $[\mathrm{P}],[\mathrm{S}]$ を製品規格まであら かじめ低減し，ごく少量のスラグ下で同溶銑の脱炭精錬 のみを行う。一方, $\mathrm{Na}_{2} \mathrm{CO}_{3}$ スラグから $\mathrm{Na}_{2} \mathrm{CO}_{3}$ を回 収できるので $\mathrm{Na}_{2} \mathrm{CO}_{3}$ の再利用が可能になり, ダスト を含めて副材料の循環使用を前提とする製鋼システムと もなる.ささらに、スラグなどの系外への廃棄物の大幅な 低減拉よびスラグ中有価成分 (P.V など)の回収も可能 になるのも特長といえる.

* 新日本製鉄 (株)第三技術研究所 (R \& D Laboratories-III, Nippon Steel Corp., 1-1-1, Edamitsu Yawatahigashi-ku Kitakyushu 805)

*2 新日本製鉄 (株) 大分製鉄所 (Oita Works, Nippon Steel Corp.)

*3 新日本製鉄 (株) 八幡製鉄所 (Yawata Works, Nippon Steel Corp.)

*4 新日本製鉄 (株) 第三技術研究所 工博 (R \& D Laboratories-III, Nippon Steel Corp.) 


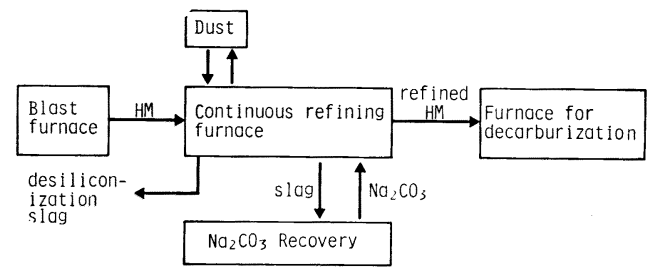

Fig. 1. Schematic diagram of the process.

このシステムを構成する要素技術である溶銑の精錬技 術, 脱炭技術およびスラグからの $\mathrm{Na}_{2} \mathrm{CO}_{3}$ 回収技術に ついて，筆者らは半工業的規模で実験を行いその技術的 可能性を確認した ${ }^{6) \sim 8)}$.

多段製鋼法の利点を享受するには，同システムによる 生産量を大きくすることが有利であるから，溶銑も大量 に精鍊されるのが適切と考えられる．この点から，本研 究では一定組成の製品を量産するのに適していると考兄 られる連続方式による, 精錬試験を行らことにした.

このような連続方式は，製鋼技術に関しては連続製鋼 法として多くの研究が進められてきた ${ }^{9) ~ 14) . ~}$ 操業可能と報告されている方法での炉形状は, 鍋型, 䡒 型のふたつに大きく分けられる.

本研究では次に示す理由から樋型炉形式を採用した。

i ) $\mathrm{Na}_{2} \mathrm{CO}_{3}$ スラグは [G] により還元されて揮発する ので，過度の粯拌を避けなければならない，攪汼を強く せずに反応界面積を大きくできる向流精鍊方式を採れ る. ii）溶銑の精鍊では [Si] をあらかじめ低減する脱 けい工程の併設が必要となるが，連続的に脱けい精錬を 行う槽を併設するのが容易である. iii) $\mathrm{Na}_{2} \mathrm{CO}_{3}$ スラ グは流動性に富み，炉外への排出が容易である.

本報告は，硧型炉での $\mathrm{Na}_{2} \mathrm{CO}_{3}$ による溶銑の連続精 錬試験結果の概要を報告するものである．本報では試験 設備操業状況および桶型炉での流れの特性についての調 査結果を述べ，続報で操業結果について検討する.

\section{2. 試験設備および試験方法}

\section{$2 \cdot 1$ 試験設備}

樋型連続精鍊炉 (以後, 連続炉とする.) は $45 \mathrm{t} / \mathrm{h}$ の 標準速度で溶銑を精鍊できる．この精錬速度は，実操業 規模での脱炭工程試験7) に必要最少量の溶銑 $(40 \mathrm{t})$ を $1 \mathrm{~h}$ 以内で供給することを目的として設定した，連続炉 は炉体, 給銑系, 出銑系, 送酸系, 副材料系, スラグ処 理系および排ガス処理系で構成されている．おの括のの 設備について説明する.

$2 \cdot 1 \cdot 1$ 炉体

鉄板溶接構造の鉄皮に塩基性耐火物たとえば $\mathrm{MgO}$ 系

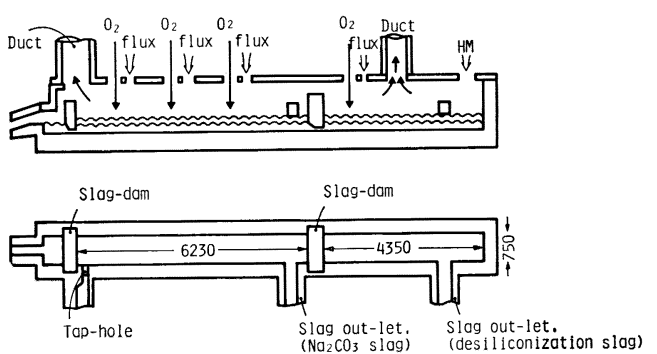

Fig. 2. Diagramatic sketch of the furnace (mm).

耐火物で内張りして炉体とした. 炉体は $\mathrm{CaO}$ 系スラ グのもとで脱けいする脱けい槽と $\mathrm{Na}_{2} \mathrm{CO}_{3}$ スラグのも とで脱りん，脱硫する脱りん槽とからなり，両槽は溶銑 浴底部上 $10 \mathrm{~cm}$ まで浸漬されている耐火物製の堰で分 離されて隣接している. 築炉後は浴長 $10.6 \mathrm{~m}$, 浴幅 0.75 $\mathrm{m}$ の浴面となる. 両槽にスラグ排出孔を各 1 ヶ炉壁部に 設けた．脱りん槽では向流精錬のため上流部に排出孔を 設けたが，脱けい槽のそれはレイアウトの制約から位置 が決定された.

炉体天井に耐火物製の蓋を用い，送酸用ランス，副材 料および精鍊温度制御のための履鉄装入孔が設けてあ る. 炉体および付帯設備の概略を示すと Fig. 2 のよう になる。

\section{$2 \cdot 1 \cdot 2$ 給銑系}

炉体に溶銑を所定速度で供給するための設備である。 傾動する架台に $45 \mathrm{t}$ 容量の給銑鍋を固定し, 所定の給 銑速度になるように傾動角速度を制御した。

スライディングノズル方式による給銑についても試験 したが，45 t/h の給銑速度ではノズル閉塞が多発したの でその使用を中止した.

\section{$2 \cdot 1 \cdot 3$ 出銑系}

精錬された溶銑を搬出するための設備である．脱りん 槽下流側の耐火物堰でスラグと分離された溶銑を，旋回 できる樋を用いて 2 ヶの運搬用溶銑鍋（45 t ）に注ぎ分 けた。

\section{$2 \cdot 1 \cdot 4$ 送酸系}

溶銑の酸化を主に酸素で行らため, 脱けい槽に 1 本, 脱りん槽に 3 本の上吹きランスを設置した. ランスは個 々に昇降, 送酸量を制御でき, 最大 $150 \mathrm{Nm}^{3} / \mathrm{h}$ の送酸 が可能である.

\section{$2 \cdot 1 \cdot 5$ 副材料系}

副材料として生石灰, 鉄鉱石および $\mathrm{Na}_{2} \mathrm{CO}_{3}$ がある. 生石灰，鉄鉱石を脱けい槽， $\mathrm{Na}_{2} \mathrm{CO}_{3}$ を脱りん槽に装 入する設備である. 帄上の各副材料ホッパーから連続的 に切り出された副材料は, 各ランスの火点部に装入され 
る. 供給速度は炉上ホッパーの重量変化から算定した. 脱りん槽の精錬温度制御のためビレットクロップ (80 〜 120 $8 \times 300 \sim 500 \mathrm{~mm}$ 長) を投入した. 炉上にベルト コンベアを設け，人力でそれに乗せて炉内に投入した。

$2 \cdot 1 \cdot 6$ スラグ処理系

炬体のスラグ排出孔，スラグ柕から流出するスラグを 搬出する設備である.

脱けいスラグはスラグパンに受けて搬出した．脱りん スラグは，同スラグから $\mathrm{Na}_{2} \mathrm{CO}_{3}$ を回収する工程での原 料であるので，同工程に適した形状にしなければならな い.同工程ではスラグを破砕して水に溶解するが，脱り んスラグは塊状に凝固させると破砕しにくくなる，スラ グの凝固と破砕とを兼ねて行らために，回転水冷円板上 にスラグを薄く流して凝固させ，破砕ロールにより 10 〜 $50 \mathrm{~mm}$ 径の小片に破砕した. 冷却後直ちに袋に入れ て保存し, $\mathrm{Na}_{2} \mathrm{CO}_{3}$ 回収工程実験の原料とした.

$2 \cdot 1 \cdot 7$ 排ガス処理系

連続炉両槽から異なつた温度，含塵量の排ガスが出 る. 両者を別々に捕集したのち，水冷ダクト内で合流さ せてバグフィルターまで導き, 除塵して大気放散した.

\section{$2 \cdot 2$ 試験法}

連続操業（最大 $120 \mathrm{~h}$ ）で試験したのち炉内溶銑を排 出し，耐火物溶損状況などを測定し再び築炉，操業する 試験形態をとつた．溶銑およびスラグが常に炉内に収容 されて操業が継続されているが, 給銑を 1 ヶの鍋で行つ ているので, 精錬作業 $1 \mathrm{~h}$ ののちに給銑鍋に溶銑を補給 するための 5〜 $15 \mathrm{~min}$ 間の操業中断があつた.

定常的な操業法は次のようになる. 所定条件で送酸お よび副材料の供給を始めたのち給銑を開始する．給銑開 始後 3 5 min で炉尻からの出銑およびスラグ排出孔か らのスラグ流出が抢こり, 定常操業に入る. 約 $1 \mathrm{~h}$ の操 業ののち給銑を終了すると, 送酸および副材料の供給を 中止し, 給銑が可能になると再度前記の操業をくり返し た.

給銑開始 $30 \mathrm{~min}$ で採取した試料が一定条件での操業 の代表組成を示していることを確かめたのち，その時刻 に給銑鍋, 脱けい槽堰近傍, 出銑流からの溶銑試料, 両 スラグ排出柕からスラグ試料を採取した。

銑鉄の [G] は化学分析, その他成分は蛍光 $\mathrm{X}$ 線法に より定量した. 脱けいスラグは蛍光 $\mathrm{X}$ 線法, 脱りんスラ グはガラスビートにしたのち蛍光 $\mathrm{X}$ 線法により定量し た。

\section{$2 \cdot 3$ 操業状況}

$2 \cdot 3 \cdot 1$ 脱けい槽

給銑鍋の傾動角速度制御で供給された溶銑は，1 本の
ランスからの酸素および鉄鉱石装入で酸化される，平均 給銑速度は目標值の $\pm 5 \%$ 以内にある。

脱けい条件は鍋ごとの [Si] 分析值をもとに決定 し た. 送酸条件は一定とし， $6 \mathrm{~mm} \phi 3$ 孔ノズル，ランス 高さ $200 \mathrm{~mm}$, 送酸速度 $150 \mathrm{Nm}^{3} / \mathrm{h}$ の条件を選んだ. 生石灰原単位はスラグ塩基度が 0.8 になるよらに，鉄 鈗石原単位は操業経験 から $50 \cdot[\mathrm{Si}]_{\mathrm{HM}}(\mathrm{kg} / \mathrm{t} . \mathrm{HM})$ と した. しかし，生石灰供給系の故障多発から目標量の装 入ができず，スラグの平均塩基度 $\left(\mathrm{CaO} / \mathrm{SiO}_{2}\right)$ は 0.33 と低かつた，スラグは泡立つていたがスラグ排出孔から 流出するため操業の支障にはならなかつた.

供給される溶銑の温度は平均 $1263^{\circ} \mathrm{C}$ と低く, しか も鉄鉱石を使用するので浴温制御は行わなかつた。

\section{$2 \cdot 3 \cdot 2$ 脱りん槽}

脱けいされた溶銑は，脱りん槽上流側の堰でスラグと 分離されて脱りん槽に入る。

送酸量は給銑鍋内溶銑 [Si] および前ヒートでの脱け い後溶銑 $\left[\mathrm{Si}\right.$ ] を参考にして決定し， $270 \sim 360 \mathrm{Nm}^{3} / \mathrm{h}$ の範囲で変更した。 ランス高さ $200 \mathrm{~mm}$ ，ノズルの 6 $\mathrm{mm} \phi 3$ 孔は一定とした。送酸量を減少させる場合には 下流側ランスから順次低減した。 これは最上流ランス近 傍にスクラップを投入するので，同部での浴䚑拌強度を 確保するためである.

ブリケット状 $\mathrm{Na}_{2} \mathrm{CO}_{3}$ は 3 本のランスの火点部近傍 に連続的に装入される。 $\mathrm{Na}_{2} \mathrm{CO}_{3}$ 原単位を実験目的に 応じて 13〜25 kg/t.HM に変更した. 炉内のスラグは 鏡面のような輝きをみせ，スラグ排出孔からの流出状況 は良好であつた。

脱りん槽では溶銑温度を制御した．脱りん槽平均溶銑 温度と炬尻での溶銑温度との差が $10 \sim 20^{\circ} \mathrm{G}$ と小さい とを確かめ，炉尻での溶銑温度を指標とした，精錬基礎 実験結果 ${ }^{15)}$ および後工程での温度低下量などから目標温 度を $1300 \sim 1350^{\circ} \mathrm{C}$ としたが，同範囲以下の例が約半 数あつた. 本操業での温度制御は目標温度域からはずれ ないようにするのが特色であり，この点から連続測温が 不可欠となる．溶銑温度が上昇しはじめるとスクラップ を装入し，下降しはじめると装入を中止する方法で制御 した. 制御結果の 1 例を示すと Fig. 3 のようになる.

脱りん槽スラグライン部の耐火物溶損速度はほとんど の場所で $0.5 \mathrm{~mm} / \mathrm{h}$ 以下であつた.

\section{3. 樋型連続精錬炉での混合特性}

樋型炉での混合特性について, 中川ら ${ }^{16)}$ は水モデル実 験装置で測定した. 混合状況は押し出し流れと完全混合 との合成モデルで近似でき，押し出し流れの割合 $P(0.4$ 


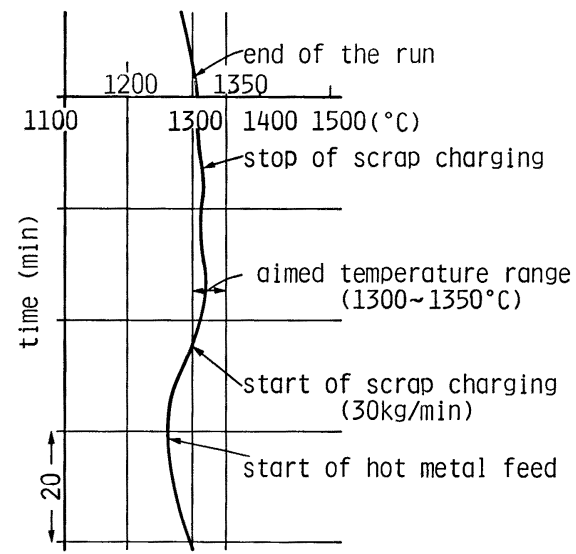

Fig. 3. An example of change of bath temperature in the temperature controlled run.

Table 1. Operational conditions of investigated runs.

\begin{tabular}{|c|c|c|}
\hline & Run $A$ & Run B \\
\hline $\begin{array}{l}\text { Hot metal feed rate } \\
\qquad(\mathrm{kg} / \mathrm{min})\end{array}$ & 710.7 & 728.3 \\
\hline $\begin{array}{l}\text { Oxygen flow rate for } \\
\text { desiliconization }\left(\mathrm{Nm}^{3} / \mathrm{T} . \mathrm{HM}\right)\end{array}$ & 3.69 & 3.75 \\
\hline $\begin{array}{l}\text { Consumption of iron ore for } \\
\text { desiliconization }(\mathrm{kg} / \mathrm{T} . \mathrm{HM})\end{array}$ & 32.2 & 31.7 \\
\hline $\begin{array}{l}\text { Oxygen flow rate for } \\
\text { dephosphorization }\left(\mathrm{Nm}^{3} / \mathrm{T}, \mathrm{HM}\right)\end{array}$ & 7.04 & 7.64 \\
\hline $\begin{array}{l}\text { Consumption of } \mathrm{Na}_{2} \mathrm{CO}_{3} \text { for } \\
\text { dephosphorization }(\mathrm{Kg} / \mathrm{T} . \mathrm{HM})\end{array}$ & 19.0 & 21.6 \\
\hline $\begin{array}{l}\text { Temperature of hot metal at } \\
\text { the outlet of furnace }\left({ }^{\circ} \mathrm{C}\right)\end{array}$ & 1315 & 1310 \\
\hline
\end{tabular}

〜0.8)は流速の増大とともに大きくなることを見出して いる，桶型炉での溶銑およびスラグの炉内成分分布，混 合特性を調查した例が見られないので，その調査を和こ なつた。

\section{1 炉内の溶銑，スラグ成分分布の測定}

定常操業時の炉内溶銑，スラグ成分分布と，同一時刻 に炉内各所で採取した試料の分析値から調查した，調査 対象としたヒートの操業条件をまとめると Table 1 の ようになり，給銑開始後 $30 \mathrm{~min}$ に試料を採取した.

脱けい槽での [Si]，脱りん槽での [P]，(Na) 拈よ び (P) の分布の例を示すと Fig. 4，5 のようになる. 横軸の尺度に用いた $L W / F_{\mathrm{m}}(L:$ 浴長 $(\mathrm{m}), W:$ : 浴幅 $(\mathrm{m}), F_{\mathrm{m}}$ : 給銑速度 $\left.(\mathrm{t} / \mathrm{min})\right)$ は, 単位重量の溶銑のス ラグとの接触面積の程度を示しかつ炉内滞留時間に対応 し，給銑速度の異なるヒート間の比較を行らための特性 值である.この結果から，

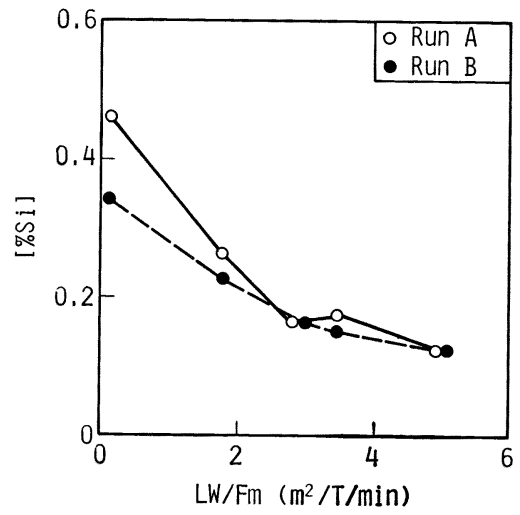

Fig. 4. Concentration profiles in the desiliconization chamber.

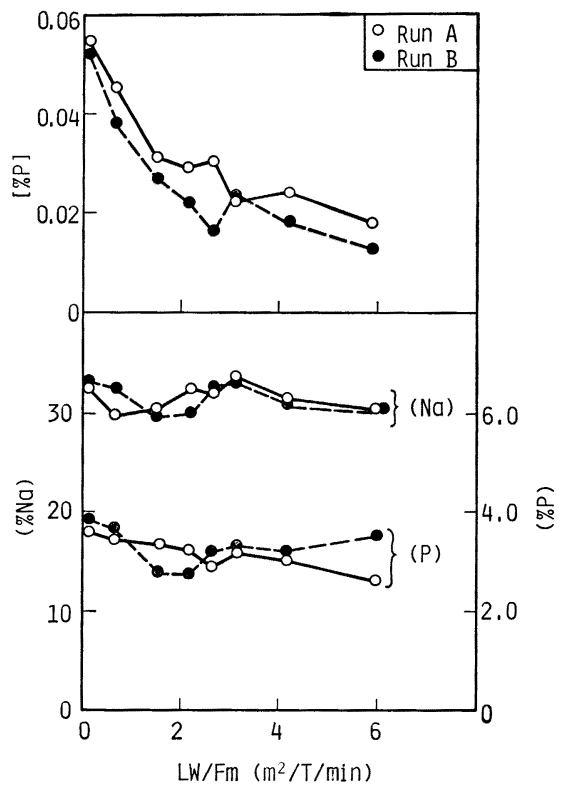

Fig. 5. Concentration profiles in the dephosphorization chamber.

i ）各成分の分布に再現性がある.

ii）脱けい, 脱りん反応の大部分は浴長 $1 / 2$ 程度で終 了している.

iii） (P) 分布に向流精錬の効果がみられる. などの知見がえられた。

\section{$3 \cdot 2$ 混合特性の測定}

連続炉での溶銑およびスラグの混合特性值 $\left(E_{\mathrm{m}}, E_{\mathrm{s}}\right.$ : ペクレ数 $N_{\mathrm{Pe}}$ の逆数) の推定を試みた. 流通反応装置 内の逆混合の度合を示すのに $N_{\mathrm{Pe}}$ が用いられ, その值 が大きいほどピストン流れに近くなる. 
(hot metal flow)

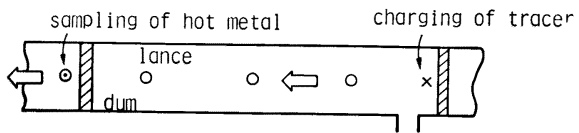

(slag flow)

charging of tracer

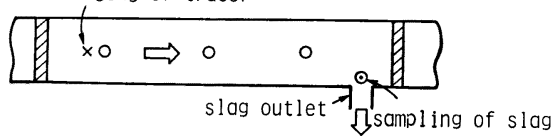

Fig. 6. Experiment for evaluation of Peclet number for metal and slag flow in the continuous refining furnace.

\section{$3 \cdot 2 \cdot 1$ 測定法}

標準操業条件（給銑速度 $740 \mathrm{~kg} / \mathrm{min}, \mathrm{Na}_{2} \mathrm{CO}_{3}$ 原単 位 $20 \mathrm{~kg} / \mathrm{t}-\mathrm{HM})$ のヒートで操業が安定する給 銑 開 始 後 $10 \mathrm{~min}$ に, トレーサー物質を投入し分析試料採取を 始めた．投入および分析試料採取位置を示すと Fig. 6 のようになる.トレーサーとして溶銑流には銅 10〜20 $\mathrm{kg}$ ，スラグ流にはホタル石 $30 \mathrm{~kg}$ を用いた。すみやかに 溶解するように小塊にして同一時刻に投入し，その後 5 〜 10 min 間隔で試料を採取した.

\section{$3 \cdot 2 \cdot 2$ 解析方法之解析結果}

流れ方向一次元の混合特性を検討する混合モデルとし て，A）合成モデル（完全混合部とピストン流れ部との 結合)，B）完全混合槽直列モデル，Ｇ）拡散モデルな ぞがあげられる17)。本報では，溶銑流，スラグ流の混合 を別々に取り扱えることおよび炬形状の影響を推定しや すいなどの利点をむつ拡散モデルをとることにした。

反応物（溶鉄，スラグ）の流れと拡散とが同時に行わ れる反応槽で，流れの方向のみの混合を検討する場合に は流れの方向を $\mathrm{x}$ 軸にとると, その濃度変化の基礎式は (1)式で与えられる.

$$
\partial C_{\mathrm{i}} / \partial t=\bar{D}_{\mathrm{e}} \cdot \partial^{2} C_{\mathrm{i}} / \partial x^{2}-\bar{u} \cdot \partial C_{\mathrm{i}} / \partial x
$$

乱流拡散係数 $\left(D_{\mathrm{e}}\right)$ および流速 $(u)$ は場所により異 なると考学られるが，ここでは便宜的にその平均值をと る.

滞留時間分布関数 $(E(\phi)$ : デルタ関数状の入口濃度 変化に対する出口濃度変化を指し, デルタ応答ともい う.) は, 過渡応答関数 $(f(\phi)$ : ステップ状の入口濃度 変化に対する出口濃度変化を指す.) に対して次のよう な簡単な関係にある.

$$
E(\phi)=d f(\phi) / d \phi
$$

宮内ら ${ }^{18)}$ は $f(\phi)$ の完全な理論解を求め, それを微分 することにより $E(\phi)$ として (3) 式を得ている. 同式を 用いて混合特性を検討した。実測された出口濃度の時間

$$
\begin{aligned}
& E(\phi)=2 \sum_{\mathrm{n}=1}^{\infty} \frac{\mu_{\mathrm{n}}\left(\sin \mu_{\mathrm{n}}+\mu_{\mathrm{n}} \cdot \cos \mu_{\mathrm{n}}\right)}{U^{2}+2 U+\mu_{\mathrm{n}}^{2}} \\
& \cdot \exp \left[U-\left(\frac{U^{2}+\mu_{\mathrm{n}}^{2}}{2 U}\right) \phi\right] \\
& U=u \cdot L / 2 D_{\mathrm{e}} \\
& \mu_{\mathrm{n}}: \cot \mu=(\mu / U-U / \mu) / 2 \text { の小さい方から第 } \mathrm{n} \text { 番目 } \\
& \text { の正根 } \\
& \text { 関数 } C(t) \text { を(4)式により書き換え，カーブ・フィッテ } \\
& \text { ィングによりUの值さらには } E_{\mathrm{m}}, E_{\mathrm{s}} \text { を推定する. } \\
& \begin{aligned}
E(\phi=t / \bar{t}) & =F \cdot \bar{t} / C_{\mathrm{o}} \cdot G(t) \\
\text { ただし } & C_{\mathrm{o}}=F \int_{0}^{\infty} C(t) d t \cdots \cdots \\
& \bar{t}=\int_{0}^{\infty} t \cdot F \cdot C / C_{\mathrm{o}} \cdot d t
\end{aligned}
\end{aligned}
$$

炉出口での溶銑中トレーサー濃度 $E(\phi)$ を炉内滞留 時間比との関係で示すと Fig. 7 のようになる.溶銑流 での測定結果はヒート間で再現性がある.（6)式から計 算される滞留時間 $\bar{t}$ は 10 13 min 程度となり, 炉形状 と給銑量とから推定される值とほぼ一致する. Fig. 7

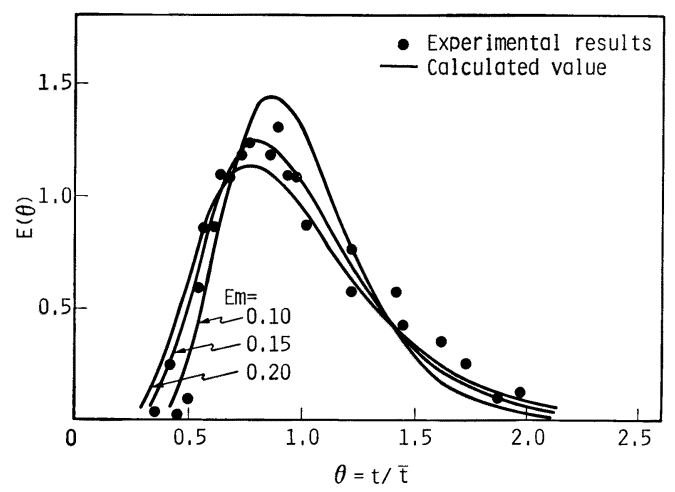

Fig. 7. Comparison of experimental results with the calculation by dispersion model in the continuous refining furnace. (Hot metal)

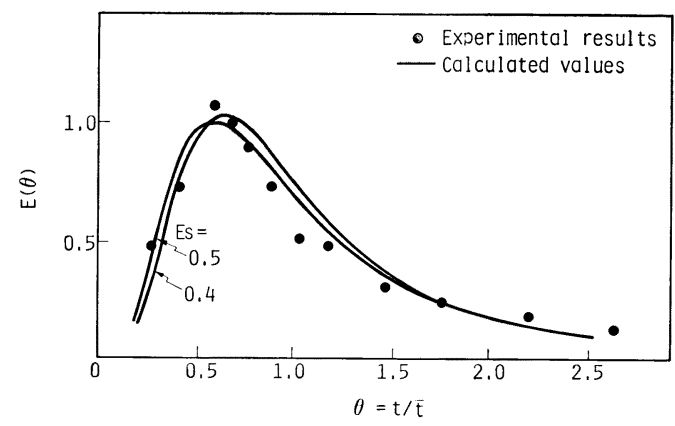

Fig. 8. Comparison of experimental results with the calculation by dispersion model in the continuous refining furnace. (Slag) 
に(3)式から計算される $E(\phi)$ の理論值を実線で示し た. 測定值との対比から, $E_{\mathrm{m}}\left(=D_{\mathrm{e} \cdot \mathrm{m}} / u_{\mathrm{m}} \cdot L\right)$ は 0.15 程 度と考光られる。

スラグ流での測定結果は再現性が十分とはい光なかつ たが，良好と思われる結果の例を示すと Fig. 8 のよう になる. 図中の実線は (3)式から計算される $E(\phi)$ の 理論值を示し, 測定結果との対比からスラグ流の $E_{\mathrm{s}}(=$ $\left.D_{\text {e.s }} / u_{\mathrm{s}} \cdot L\right)$ は 0.5 程度と考光られる.

以上の測定から, 本試験条件での $E_{\mathrm{m}}, E_{\mathrm{s}}$ はそれぞれ $0.15,0.5$ と推定された. この值は, 完全混合槽直列モ デルに対応させると溶銑流については $3 \sim 4$ 槽, スラグ 流については $2 \sim 3$ 槽程度のピストン流特性に対応する と考党られる.

\section{4. 結}

\section{言}

$\mathrm{Na}_{2} \mathrm{CO}_{3}$ による溶銑事前精錬を前提とした, $\mathrm{Na}_{2} \mathrm{CO}_{3}$ を循環使用する製鋼システムを提案した. $\mathrm{Na}_{2} \mathrm{CO}_{3}$ を 用いて溶銑を連続精鍊する試験を $45 \mathrm{t} / \mathrm{h}$ 規模で行つ た. 向流精鍊方式を採れるなどの理由から，本試験では 炉形式として樋型炉を採用した。

塩基性耐火物て築造された炉は脱けい槽, 脱りん槽の 2 槽に分けられ，脱りん槽では脱けいされた溶銑が向流 方式で精錬された，炉体には付带設備として, 給銑系, 出銑系, 送酸系, 副材料系, スラグ処理系および排気系 の設備を備えている.

安定した操業および脱りん槽溶銑温度制御が可能であ ることを確かめた．連続炬での精錬時炬内成分分布およ び脱りん槽内の溶銑流拉よびスラブ流の混合特性の調查 から次項があきらかになつた。

i ) 脱りん槽では上流側ほど $[\mathrm{P}],(\mathrm{P})$ が高く, 向 流精錬特有の忓内成分分布が確かめられた.

ii）溶銑流，スラグ流にトレーサーを添加し，おのお のの混合特性值 $E_{\mathrm{m}}, E_{\mathrm{s}}$ を測定しそれぞれ $0.15,0.5$ が得られた.

$$
\begin{aligned}
& \\
& C_{\mathrm{i}}: \text { 反応物質 } \mathrm{i} \text { の濃度 } \\
& t: \text { 時間 } \\
& \overline{D_{\mathrm{e}}}: \text { 平均乱流改散係数 } \\
& x: \text { 流机方向距離 } \\
& \bar{u}: \text { 平均流速 } \\
& \phi \quad: \text { 径過時間比 }(: t / \bar{t}) \\
& \bar{t}: \text { 平均滞留時間 } \\
& L: \text { 炉長 }
\end{aligned}
$$

$F ：$ 溶銑またはスラグ流量

$C_{0}:$ トレーサー投入量

$\left(\mathrm{cm}^{3} / \mathrm{s}\right)$

\section{交献}

1) 森谷尚玄, 藤井正信：鉄と 鋼，63 (1977), S 622

2 ) 山本里見, 梶岡博幸: 鉄々鋼, 65 (1979), S 210

3) 丸川雄浄, 城田良康, 姉崎正治, 平原弘章: 鉄と 鋼, 67 (1981), p. 323

4 ) 山田健三, 宮下芳雄, 栗山伸二, 中島龍一, 半明 正之，田口喜代美：鉄と鋼，66 (1980), A 141

5 ) たとえば 井上博文, 重野芳人, 德田昌則, 大谷 正康：鉄之鋼，63 (1977), S 575

福沢 章, 中川龍一, 吉松史朗, 佐藤 彰, 三井 達郎, 尾崎 太：鉄と鋼, 64 (1978), p. 2109 成田貴一, 牧野武久, 松本 洋, 彦坂明秀: 鉄と 鋼, 66 ((1980), S 728

梅沢一誠, 二杉蒠造，有馬良士：鉄と鋼，66 (1980), S 729

中村 泰, 原島和海, 福田義盛: 鉄と鋼, 67 (1981), p. 2138

$6)$ 山本里見, 藤掛陽藏, 坂口庄一, 藤浦正己, 梶阙 博幸，吉井正孝，福岡弘美：鉄と鋼，65（1979）， $\mathrm{S} 212$

山本里見, 藤掛陽蔵, 松尾輝夫, 梶岡博幸, 吉井 正孝，坂口庄一：鉄と鋼，65 (1979), S 732

7 ) 小久保一郎, 尾形昌彦, 小敬俊洋, 中嶋睦生, 桑 原正年，山本里見，山口武和：鉄と鋼，65(1979) $\mathrm{S} 213$

8 ）松尾輝夫, 横大路照男, 吉田誠, 山本誠二, 山 本里見，福田昭一：鉄と鋼，69 (1983)， p. 937

9 ) たとえば, D.R.G. Davies, M.J. RhydDERch, and L.J. Shaw: JISI, 205 (1967), p. 180

10) たと党ば, $A$. Berthet, $J$. Rouanet, $P$. VaySsiere, and $B$. TREnTINI: JISI, 207 (1969), p. 790

11) たと光ば, H.K. Worner, F.H. BAKer, I. H. Lassam, and $R$. Siddons: J. Met., 21 (1969), p. 50

12) E.M. Rudzki, H. L. Gills, B. K. Pease, and G.E. Wieland: J. Met., 21 (1969), p. 57

13) M.A. Glinkov: Proceedings of the Meeting "Alternative routes to Steel", Iron Steel Inst London (1971), p. 88

14）たとえば, 中川龍一, 吉松史朗, 上田卓弥, 三井 達郎, 福沢章, 佐藤彰, 尾崎太: 鉄々鋼, 59 (1973), p. 414

15）山本里見, 藤掛陽蔵, 坂口庄一：鉄と鋼，68 (1982), p. 1896

16）中川龍一, 上田卓弥, 渡辺幸雄, 斎藤 博：鉄と 鋼, 56 (1970), S 65

17) $J$. Szeckely and $N . J$. Themelis: Rate Phenomena in Process Metallurgy (1971), p. 515 [Wiley-Interscience, A Division of John Willey and Sons Inc.]

18) 矢木 栄, 宮内照勝: 化学工学, 17 (1953), p. 382 